\title{
Notes on Finnish Sepsidae and Muscidae (Diptera)
}

\author{
Adrian C. Pont \\ 38 Gatehampton Road, Goring-on-Thames, Reading RG8 OED, England
}

\section{Additions and corrections to the Finnish list of Sepsidae}

During a revision of sepsid material in the University Zoological Museum, Helsinki, eight species were found new to Finland. Furthermore, one species of doubtful status in the last list (Hackman 1980) can be confirmed as a Finnish species, whilst one species has to be deleted. The number of Finnish species in this little family is thus increased from 24 to 31 .

Sepsis nigripes Meigen, 1826. In the list only as a "residual" name from earlier lists. Confirmed as a Finnish species from $A l$ : Finström and Saltvik, $2 \sigma^{\top}$.

S. luteipes Melander \& Spuler, 1917. Deleted. Specimens so identifled appear only to be a form of the common and variable S. punctum (Fabricius, 1794).

S. biflexuosa Strobl, 1893. Ab: Korpo Jurmo, 10’', 2ᄋ; Nagu Sälgskär, 3ơ', 3o. Ks: Kuusamo, $10^{7}$.

S. thoracica (Robineau-Desvoidy, 1830). Ab: Korpo Jurmo, 10?.

Ortalischema albitarse (Zetterstedt, 1847). Sa: Punkaharju, 10', 20. Collected on horse droppings by the writer.

Themira biloba Andersson, 1975. N: Helsinki, 10’. Also 1o labelled "Sagittaria" by L. Tiensuu, most probably therefore $K a$.

T. germanica Duda. 1926. Ab: Karislojo, 1 . . $N$ : Hangö, 1o; Täcktom, 1o; Tvärminne, 10’. St: Reposaari, 1․ Ta: Padasjoki, $10^{7}$.

T. lucida (Staeger, 1844). Common and widespread, and evidently confused with $T$. minor (Haliday, 1833). Seen from the following provinces: Al, Ab, N, Ta, Sa, Oa, Tb, ObS, Ks, Li. Zetterstedt (1860) recorded 1o of T. lucida collected at Helsinki by Bonsdorff, but the record has not been accepted subsequently. Bonsdorff's o has been located and is indeed T. lucida .

T. malformans Melander \& Spuler, 1917. Lkw: Muonio, 207. Li: Utsjoki, 10, 1 . .

T. paludosa Elberg, 1963. Previously known only from the type-locality in Estonia. $A b$ : Ka-

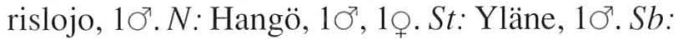
Tuovilanlaks, 10. Ks: Kuusamo, 10 .

Further details on taxonomy and distribution will appear in a volume on Sepsidae for the series Fauna Entomologica Scandinavica by the writer, now nearing completion.

\section{Myospila bimaculata (Macquart, 1834) (Mus- cidae), new to Finland}

Sa: Punkaharju, in cattle pasture, 10.VII.1988, 20 , taken together with $10^{7} 1$ of $M$. meditabunda (Fabricius, 1782), collected and identified by the writer. The occurrence of this species in Finland was to be expectecl, since it has long been confused with $M$. meditabunda (see Gregor 1968) and is known in NW Europe from Denmark, Norway, Sweden, and the N European Territory of the USSR (Pont in Soós \& Papp 1986).

\section{References}

Gregor, F. 1968: Die Europeischen Arten der Gattung Myospila Rond. (Dipt., Muscidae). - Acta Entomol. Bohemoslov. 65:299-318.

Hackman, W. 1980: A check list of the Finnish Diptera. II. Cyclorrhapha. - Notulae Entomol. 60:117-162.

Soós, A. \& Papp, L. (eds.) 1986: Catalogue of Palaearctic Diptera 11: Scathophagidae-Hypodermatidae. - Elsevier, Amsterdam - Oxford - New York - Tokyo, 312 pp. Zetterstedt, J. W. 1860: Diptera Scandinavica 14:6191-6609. — Lundbergiana, Lundae. 